\title{
PENGARUH MODEL PEMBELAJARAN KOOPERATIF TIPE THINK-PAIR-SHARE DENGAN METODE EKSPERIMEN TERHADAP HASIL BELAJAR PESERTA DIDIK MAN LOMBOK BARAT TAHUN PELAJARAN 2017/2018
}

\author{
Juliana Audina Pratiningsih*, Hairunnisyah Sahidu, Kosim \\ Program Studi Pendidikan Fisika, Universitas Mataram \\ *Email: nongnaning@gmail.com
}

\begin{abstract}
This research is aimed to find the effect of cooperative model learning think pair share type with experiment method toward learning physics result of the students at man west Lombok in academic year 2017/2018. The kind of this research is quasi experiment with Untreated control group design with pretest-posttest research design. The population of this research is all of the XI students of MAN West Lombok which consist of 34 students. Sampling jenuh technique is a way of taking the sample, while XI IPA 1 students as experiment class and XI IPA 2 as control class. The instruments that used are; multiple choice test and observation sheet. The amount of the multiple choice test are 25 questions where the test before has been through validity test, reliability, different capacity and standard of questions difficulty, while the observation sheet used to measure the affective and psychomotor score. Based on the result of the research that achieved from the mean score for pretest of experiment class is 40,19 and control class is 37,45, while the mean score of post-test experiment class is 73,52 and control class is 51,27. The hypothesis of the research is tested using t-test polled varians with significant standard 5\% and achieved $t_{\text {result }} 7,646$ and $t_{\text {table }} 2,021$. Based on the criteria of hypothesis test, if $t_{\text {result }}>t_{\text {table, }}$ it means $H_{o}$ released and $H_{a}$ accepted, where it can conclude that there is a effect of cooperative model learning think pair share type with experiment method toward learning physics result of the students at man west Lombok in academic year 2017/2018.
\end{abstract}

Keywords: Cooperatvie, think pair share, experiment method, and learning result

\section{PENDAHULUAN}

Pendidikan dapat dimaknai sebagai proses mengubah tingkah laku peserta didik agar menjadi manusia dewasa yang mampu hidup mandiri dan sebagai anggota masyarakat dalam lingkungan alam sekitar dimana individu itu berada. Pendidikan tidak hanya mencakup pengembangan intelektualitas saja, akan tetapi lebih ditekankan pada proses pembinaan kepribadian peserta didik secara menyeluruh sehingga peserta didik menjadi lebih dewasa. Dalam dunia pendidikan, keberhasilan dalam pembelajaran ditentukan dengan kualitas dan mutu pendidikan, khususnya di sekolah. Salah satu upaya untuk meningkatkan mutu pendidikan dan keberhasilan peserta didik dalam mempelajari fisika adalah dengan cara memperbaiki proses pembelajaran. Proses pembelajaran yang di maksud antara lain yaitu memperbaiki cara mengajar guru dengan mengggunakan model pembelajaran dan metode yang bervariasi (Juraini,et all., 2016).

Ada banyak model dan metode pembelajaran yang dikembangkan para ahli dalam mengoptimalkan hasil belajar. Akan tetapi, bukan berarti semua model dan metode cocok untuk setiap materi. Selain itu bukan hal mudah bagi guru memilih model dan metode yang sesuai dengan materi dalam mengajar, karena di dalam setiap kelas kemampuan akademik peserta didik yang berbeda-beda. Jika seorang guru mampu memilih model dan metode pembelajaran yang sesuai,maka peserta didik yang belajar dengan model pembelajaran yang tepat akan mengalami perubahan ke arah yang lebih baik, baik dari segi pengetahuan, keterampilan 
maupun sikap. Seorang guru dapat menciptakan proses pembelajaran yang aktif, kreatif, efektif, inovatif dan menyenangkan yang mampu mengajak peserta didik untuk memahami materi pelajaran fisika dan aplikasinya dalam kehidupan sehari-hari dengan mudah.

Berdasarkan hasil observasi yang telah dilaksanakan di MAN Lombok Barat, diketahui paling tidak terdapat dua hal yang perlu di kemukakan yaitu dari sisi guru dan peserta didik. Dari sisi guru, pengelolaan pembelajaran belum terlaksana secara maksimal yang di tandai dengan guru belum menerapkan model pembelajaran yang efektif dan menarik (masih menggunakan model pembelajaran konvensional), sedangkan dari sisi peserta didik yaitu kurangnya minat peserta didik terhadap pelajaran fisika, peserta didik menganggap bahwa fisika merupakan mata pelajaran yang banyak menghitung dan membosankan sehingga timbul rasa malas untuk belajar fisika dan ternyata hasil belajarnya sebagian belum tuntas. Hasil belajar peserta didik dapat dilihat dalam tabel data nilai ujian semester 2 peserta didik kelas X IPA MA Negeri Lombok Barat tahun ajaran 2016/2017 mata pelajaran Fisika ditunjukkan pada Tabel 1.

Tabel 1. Nilai ujian Semester 2 Tahun Pelajaran 2016/2017

\begin{tabular}{cccccc}
\hline No & Kelas & $\begin{array}{c}\text { Jumlah peserta } \\
\text { didik }\end{array}$ & Nilai Rata-rata & KKM & Keterangan \\
\hline 1 & X IPA 1 & 23 & 53,82 & 65 & Tidak Tuntas \\
2 & X IPA 2 & 23 & 53,20 & 65 & Tidak Tuntas \\
\hline
\end{tabular}

Berdasarkan permasalahan tersebut, seorang guru dituntut menggunakan model pembelajaran yang bervariasi mengarahkan peserta didik untuk aktif dan menarik minat peserta didik untuk belajar fisika. Model pembelajaran tersebut yang mampu mengarahkan peserta didik menemukan dan membuktikan sendiri permasalahan yang diberikan oleh guru dengan melakukan eksperimen sehingga peserta didik mampu memahami konsep-konsep fisika dan mengaplikasikan dalam kehidupan seharihari. Pada akhirnya peneliti menawarkan suatu alternatif solusi pembelajaran yang sesuai dengan permasalahan tersebut dan sesuai juga dengan tuntutan kurikulum saat ini yakni dengan menerapkan model pembelajaran kooperatif tipe Think-PairShare dengan metode eksperimen. Menurut Priyanto (dalam Trianto, 2014) pembelajaran kooperatif merupakan salah satu model pembelajaran kelompok yang memiliki aturan-aturan tertentu. Prinsip dasar pembelajaran kooperatif adalah

(Sumber: Arsip Guru Mata Pelajaran Fisika, 2016)

peserta didik membentuk kelompok kecil dan saling mengajar sesamanya untuk mencapai tujuan bersama.Model Pembelajaran kooperatif tipe Think-PairShare merupakan model pembelajaran yang efektif untuk membuat variasi suasana pola diskusi. Prosedur yang digunakan dalam tipe Think-Pair-Share dapat memberi peserta didik lebih banyak waktu berpikir, merespon dan saling membantu. Tipe pembelajaran

Think-Pair-Share dikembangkan dari model pembelajaran kooperatif oleh Frank Lyman dan rekannya di Universitas Maryland dan terdiri dari tiga fase yang terorganisir dengan baik, yaitu, Think atau berpikir, Pair atau berpasangan, dan Share atau berbagi. Secara singkat alur proses pembelajaran dalam tipe Think-PairShare dimulai dengan guru mengajukan suatu pertanyaan, kemudian peserta didik berpasangan dan mendiskusikan apa yang telah di peroleh, peserta didik berbagi jawaban terhadap pertanyaan yang telah diajukan (Trianto, 2014). Selain 
menggunakan model pembelajaran, diperlukan juga suatu metode yang dapat menunjang kegiatan pembelajaran, salah satu metode yang dapat digunakan adalah metode eksperimen. Metode eksperimen adalah suatu cara penyampaian pengajaran dengan melakukan kegiatan percobaan untuk menemukan sendiri apa yangdipelajari baik secara individu maupun kelompok, sehingga siswa mampu mengecek kebenaran suatu hipotesis atau membuktikan sendiri apa yang dipelajari (Nurqomariah,et all., 2015).

Dapat disimpulkan bahwa model pembelajaran kooperatif tipe Think-PairShare dengan metode eksperimen adalah suatu teknik sederhana dimana peserta didik berpasangan dengan peserta didik lainnya dalam melakukan suatu percobaan untuk membuktikan suatu pertanyaan yang telah diberikan. Adapun sintaks dari model pembelajaran kooperatif tipe Think-PairShare dengan metode eksperimen yaitu pertama guru mengajukan suatu pertanyaan kepada peserta didik, kemudian peserta didik berpasangan dengan peserta didik lainnya melakukan suatu percobaan untuk membuktikan pertanyaan tersebut dan terakhir peserta didik menyimpulkan suatu pertanyaan yang telah diberikan.

Keberhasilan dari keseluruhan langkahlangkah tersebut dapat diukur dengan hasil belajar peserta didik yang diuji dengan instrumen berupa tes pilihan ganda dan lembar observasi. Hasil belajar merupakan perubahan pada diri individu dari segi kognitif, afektif, maupun psikomotor yang didapatkannya sebagai akibat dari suatu proses belajar(Azmi, et all., 2016).

\section{METODE PENELITIAN}

Penelitian ini termasuk jenis penelitian quasi experiment yang merupakan suatu cara untuk menguji hubungan sebab, dimana peneliti memberikan perlakuan kepada subyek untuk menentukan apakah perlakuan tersebut memiliki dampak atau pengaruh pada variabel atau faktor hasil tertentu.Pada penelitian ini ada tiga variabel yang menjadi fokus penelitian yaitu variabel bebas, variabel terikat dan variabel kontrol. Variabel bebas adalah model pembelajaran, variabel terikat adalah hasil belajar fisika peserta didik, dan variabel kontrol adalah berupa materi, tujuan pembelajaran, instrumen yang digunakan, dan cara penilaian. Desain penelitian yang digunakan adalah untreated control group design with pretest-posttest. Desain penelitiannya dapat dilihat pada Tabel 2 berikut.

Tabel 2. Desain Penelitian

\begin{tabular}{lccc}
\hline Kelompok & Pretest & Perlakuan & Posttest \\
\hline Eksperimen & $\mathrm{O}_{1}$ & $\mathrm{X}_{1}$ & $\mathrm{O}_{2}$ \\
Kontrol & $\mathrm{O}_{3}$ & $\mathrm{X}_{2}$ & $\mathrm{O}_{4}$ \\
\hline \multicolumn{4}{c}{ (Setyosari, 2013) }
\end{tabular}

Keterangan:

$\mathrm{X}_{1}=$ Pembelajaran menggunakan model pembelajaran kooperatif tipe ThinkPair-Share dengan metode eksperimen.

$\mathrm{X}_{2}=$ Pembelajaran menggunakan model pembelajaran konvensional.

$\mathrm{O}_{1}$ dan $\mathrm{O}_{3}=$ pemberian tes awal pada kedua sampel.

$\mathrm{O}_{2}$ dan $\mathrm{O}_{4}=$ pemberian tes akhir pada kedua sampel.

Adapun teknik pengambilan sampel dilakukan dengan teknik sampling jenuh, yakni teknik pengambilan sampel di mana semua anggota populasi digunakan sebagai sampel. Sampel yang dipergunakan dalam penelitian ini yaitu peserta didik kelas XI IPA, yaitu XI IPA 1 yang berjumlah 21 orang sebagai kelas eksperimen XI IPA 2 yang berjumlah 22 sebagai kelas kontrol.

Tehnik pengambilan data dilakukan dengan metode tes hasil belajar peserta didik. Tes ini menggunakan teknik tes tertulis dan tes kinerja. Tes tertulis berupa tes pilihan ganda sebanyak 25 soal yang mengacu pada kemampuan kognitif peserta 
didik. Tes yang dilakukan berupa tes awal (pretest) dan tes akhir (posttest). Sebelum dilakukan tes, soal terlebih dahulu diuji cobakan untuk mengetahui validitas, realibilitas, daya beda dan taraf kesukarannya. Analisis data menggunakan uji statistik parametrik $t$-test polled varians, yang sebelumnya telah diuji normalitas data menggunakan uji chi kuadrat dan homogenitas data menggunakan uji F.

\section{HASIL DAN PEMBAHASAN}

Penelitian ini bertujuan untuk mengetahui pengaruh model pembelajaran kooperatif tipe Think-Pair-Share dengan metode eksperimen terhadap hasil belajar fisika peserta didik MAN Lombok Barat tahun pelajaran 2017/2018. Perlakuan yang diberikan berupa model pembelajaran kooperatif tipe Think-Pair-Share dengan metode eksperimen pada kelas eksperimen dan pembelajaran konvensional pada kelas kontrol.

Hasil penelitian ini meliputi hasil belajar kognitif, hasil belajar psikomotor dan hasil belajar afektif. Hasil belajar kognitif berupa hasil uji coba instrumen, analisis data tes awal, analisis data tes akhir. Data yang terkumpul terdiri atas data tes awal dan data tes akhir hasil belajar fisika peserta didik (dalam ranah kognitif sedangkan psikomotor dan afektif sebagai data pendukung) pada materi pokok suhu dan kalor.

\section{Deskripsi Hasil Belajar Kognitif}

a. Hasil Uji Coba Instrumen

Uji coba instrumen dilaksanakan di MAN Lombok Barat pada kelas XII IPA 1 dengan jumlah peserta didik 23 orang. Hasil uji coba instrumen di dapatkan 22 item soal yang valid, 25 item soal yang reliabel. Indeks Kesukaran jumlah soal mudah sebanyak 6, jumlah soal sedang sebanyak 17 dan jumlah soal sukar sebanyak 2 . Tingkat daya beda di dapatkan 19 item soal yang diterima, 5 item soal yang diperbaiki, dan 1 item soal yang ditolak.

\section{b. Analisis Data}

Data hasil belajar terlebih dahulu diuji homogenitas dan normalitasnya, setelah diuji di dapat bahwa data homogen dan terdistibusi normal. Data hasil belajar peserta didik didapatkan dari hasil pelaksanaan pre-test dan post-test. Hasil belajar pada kedua kelas yang dijadikan sampel yakni XI IPA 1 dan XI IPA 2 di MAN Lombok Barat berupa tes pilihan ganda sebanyak 25 soal dengan materi suhu dan kalor. Soal-soal yang digunakan adalah soal yang telah diuji validitas, reliabilitas, tingkat kesukaran, dan daya beda soal. Sebelum diberikan perlakuan kedua kelas tersebut, terlebih dahulu dilakukan tes awal untuk mengetahui kemampuan awal peserta didik. Setelah diberi perlakuan pada akhir pertemuan dilakukanlah tes akhir untuk mengetahui hasil belajar peserta didik. Adapun hasil tes awal dan akhir peserta didik pada kelas eksperimen dan kelas kontrol dapat dilihat pada gambar 1 berikut.

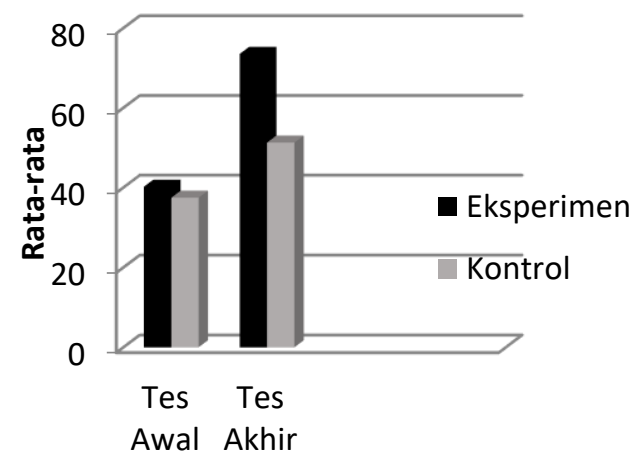

Gambar 1. Histogram Hasil Tes Awal dan Akhir pada Kedua Sampel

Berdasarkan gambar 1, terdapat perbedaan rata-rata hasil tes awal dan tes akhirpeserta didik pada kedua kelompok sampel. Kelas eksperimen memiliki nilai rata-rata tes awal yang tinggi dibandingkan kelas kontrol. Sebelum diberi perlakuan, nilai rata-rata tes awal kelas eksperimen adalah 40,19, sedangkan untuk kelas 
kontrol adalah 37,45.Kelas eksperimen juga memiliki nilai rata-rata tes akhir yang tinggi dibandingkan kelas kontrol. Sesudah diberi perlakuan, nilai rata-rata tes akhir kelas eksperimen adalah 73,52, sedangkan untuk kelas kontrol adalah 51,27.

c. Uji Hipotesis

Dalam penelitian ini, uji hipotesis dilakukan untuk mengetahui apakah terdapat pengaruh model pembelajaran kooperatif tipe Think-Pair-Share dengan metode eksperimen terhadap hasil belajar fisika peserta didik MAN Lombok Barat yang diterapkan terhadap kelas eksperimen.
Uji hipotesis yang dilakukan tergantung dari kriteria normalitas dan homogenitasdata hasil tes akhir kelas eksperimen dan kontrol serta jumlah peserta didik untuk kedua kelas. Berdasarkan hasil perhitungan diketahui bahwa data kedua kelas terdistribusi normal dan homogen serta jumlah peserta didik untuk kelas eksperimen dankontrol berbeda, maka uji hipotesis yang digunakan adalah statistik parametric berupa t-test polled varians. Hasil analisis uji hipotesis data terhadap hasil belajar fisika peserta didik dapat dilihat pada Tabel 3 berikut.

Tabel 3 Hasil Uji Hipotesis

\begin{tabular}{lccccc}
\hline \multicolumn{1}{c}{ Kelompok } & $\begin{array}{c}\text { Jumlah Peserta } \\
\text { didik }(\boldsymbol{n})\end{array}$ & Rata-rata $(\overline{\boldsymbol{X}})$ & Varians $\left(\boldsymbol{S}^{\mathbf{2}}\right)$ & $\boldsymbol{t}_{\text {hitung }}$ & $\boldsymbol{t}_{\text {tabel }}$ \\
\hline Eksperimen & 21 & 73,52 & 93,50 & & 2,021 \\
Kontrol & 22 & 51,27 & 89,30 & 7,646 & \\
\hline
\end{tabular}

Dari hasil perhitungan diperoleh $t_{\text {hitung }}=7,645$ dan $t_{\text {Tabel }}=2,021$ pada taraf signifikan 5\% untuk derajat kebebasan $41\left(d k=n_{1}+n_{2}-2=21+22-2=\right.$ 41). Berdasarkan kriteria pengujian $t_{\text {hitung }}>t_{\text {Tabel }}$ yaitu $7,646>2,021$, sehingga dapat disimpulkan Ho ditolak dan Ha diterima. Dengan demikian, dapat disimpulkan bahwa model pembelajaran kooperatif tipe Think-Pair-Share dengan metode eksperimen berpengaruh terhadap hasil belajar fisika peserta didik MAN Lombok Barat.

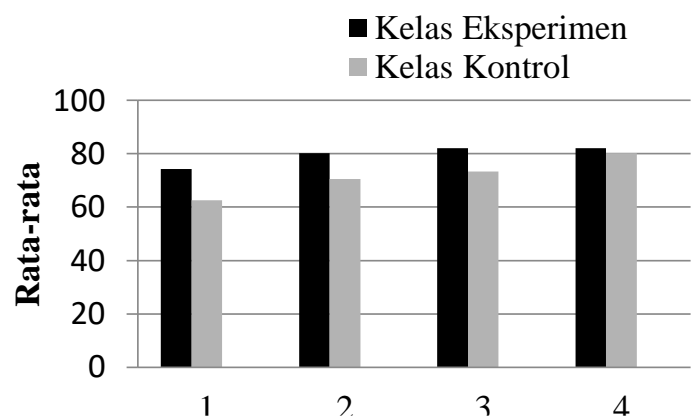

Gambar 2. Grafik Hasil Belajar Ranah Psikomotor
2. Deskripsi Hasil Belajar Psikomotor

Adapun hasil penelitian ranah psikomotor kelas eksperimen dan kelas kontrol dapat dilihat pada gambar 2 .

Berdasarkan gambar 2, didapatkan bahwa hasil belajar ranah psikomotor kelas eksperimen lebih tinggi dibandingkan dengan kelas kontrol walaupun kedua sampel mengalami kenaikan setiap pertemuan.

3. Deskripsi Hasil Belajar Afektif

Adapun hasil penelitian ranah psikomotor kelas eksperimen dan kelas kontrol dapat dilihat pada gambar 3 berikut.

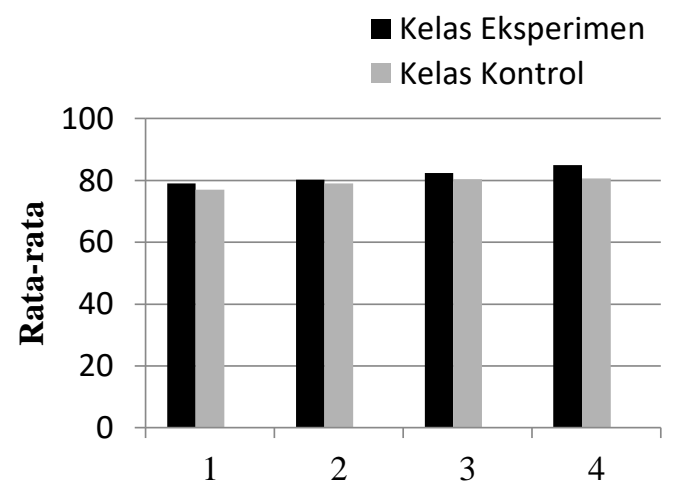

Gambar 3. Grafik Hasil Belajar Ranah Afektif 
Pada gambar 3, didapatkan bahwa hasil belajar ranah afektif kelas eksperimen lebih tinggi dibandingkan dengan kelas kontrol.

Berdasarkan hasil penelitian, ada peningkatan rata-rata nilai tes akhir dari tes awal yang telah dilakukan. Peningkatan rata-rata nilai ini terjadi pada kedua kelas sampel. Pada kelas eksperimen yang diberikan perlakuan model pembelajaran kooperatif tipe Think-Pair-Share dengan metode eksperimen memiliki nilai rata-rata tes awal dan tes akhir lebih tinggi dibandingkan dengan kelas kontrol yang diberikan perlakuan pembelajaran konvensional. Walaupun keduanya memiliki rata-rata nilai yang meningkat tetapi pada kelas yang diterapkan model pembelajaran kooperatif tipe Think-PairShare dengan metode eksperimen jauh lebih baik dari pada kelas yang diterapkan model pembelajaran konvensional terbukti dengan perbedaan rata-rata nilai tes akhir pada kedua kelas terlihat pada Tabel 4.

Selain itu, berdasarkan analisis uji statistik dengan uji-t polled varians diperoleh $t_{\text {hitung }}$ lebih besar dari pada $t_{\text {tabel }}$ yang nilainya dapat dilihat pada Tabel 4.4. Hasil ini membuktikan bahwa model pembelajaran kooperatif tipeThink-PairShare dengan metode eksperimen berpengaruh terhadap hasil belajar fisika peserta didik sehingga $\mathrm{H}_{0}$ ditolak dan $\mathrm{H}_{\mathrm{a}}$ diterima, artinya ada pengaruh model pembelajaran kooperatif tipe Think-PairShare dengan metode eksperimen terhadap hasil belajar fisika peserta didik.

Berdasarkan uji statistik, didapat bahwa model pembelajaran kooperatif tipe Think-Pair-Share dengan metode eksperimen lebih baik dari pada model pembelajaran konvensional. Hal ini menunjukkan bahwa pada kelas yang menggunakan dengan model pembelajaran kooperatif tipe Think-Pair-Share dengan metode eksperimen akan menghasilkan hasil belajar fisika yang lebih baik dari pada kelas yang menerapkan model pembelajaran konvensional.

Mengacu pada tinjauan pustaka bahwa model pembelajaran kooperatif tipe Think-Pair-Share dengan metode eksperimen memberikan kesempatan kepada semua peserta didik untuk aktif dalam mencari tahu terhadap materi yang sedang dipelajari, serta bertanggung jawab untuk belajar dan mengajarkan kepada anggota lain terkait materi yang dipelajarinya. Menerapkan model pembelajaran kooperatif tipe Think-PairShare dengan metode eksperimen dapat meningkatkan hasil belajar fisika peserta didik karena proses pembelajaran kooperatif tipe Think-Pair-Share dengan metode eksperimen sesuai dengan karakteristik yang dimiliki peserta didik yang lebih mudah mengingat sesuatu berdasarkan hasil penemuannya melalui percobaan maupun dari hasil diskusi kelompok.

Hasil penelitian ranah psikomotor dan afektif juga diukur berdasarkan observasi peneliti. Kelas eksperimen memiliki hasil belajar ranah psikomotor dan afektif yang cukup tinggi dibandingkan dengan kelas kontrol. Hasil belajar ranah psikomotor dan afektif juga memiliki pengaruh pada hasil belajar peserta didik ranah kognitif. Antusias peserta didik dalam belajar akan mempengaruhi hasil belajar pada ranah psikomotor dan afektif, karena peserta didik lebih fokus mengikuti setiap tahap pembelajaran,sehingga memudahkan peserta didik memahami suatu konsep yang ingin dipelajari, hal inimenunjukkan tiga ranah saling berhubungan dalam meningkatkan hasil belajar fisika peserta didik. Hal tersebut terlihat dari pencapaian rata-rata hasil akhir peserta didik kelas eksperimen dan kontrol.

Temuan dalam penelitian ini diperkuat beberapa penelitian sebelumnya 
diantaranya penelitian yang dilakukan oleh Ni'mah, et all (2014), menyatakan bahwa terdapat pengaruh model pembelajaran kooperatif tipe Think-Pair-Share dengan metode eksperimen terhadap hasil belajar fisika peserta didik. Penelitian Wahyuni, et all (2013) menunjukkan bahwa metode eksperimen dengan strategi Think-PairShare dalam model pembelajaran diskusi berpengaruh positif terhadap hasil belajar siswa ranah kognitif pada materi perpindahan panas di kelas VII SMP Negeri 2 Buduran Sidoarjo. Penelitian Surayya, et all ( 2014) menyatakan terdapat perbedaan hasil belajar antara siswa yang mengikuti model pembelajaran Think-Pair-Share dengan siswa yang mengikuti model pembelajaran konvensional dan tidak terdapat pengaruh interaksi antara model pembelajaran Think-Pair-Share dan keterampilan berpikir kritis terhadap hasil belajar.Penelitian Winayah et all(2013) menyatakan terdapat peningkatan hasil belajarsiswa dengan penerapan model pembelajaran kooperatif tipe Think-PairShare dengan metode praktikum. Penelitian Nurilah, et all., (2013) menyatakan bahwa model kooperatif tipe TPS dengan metode eksperimen disertai teknik concept mapping berpengaruh terhadap sikap ilmiah peserta didik dan hasil belajar fisika peserta didik kelas $\mathrm{X}$ di SMAN 2 Tanggul. Hasil penelitian Ampriyadi (2014:51) menyimpulkan menyatakan bahwa penerapan model pembelajaran kooperatif tipe Think-Pair-Share dapat meningkatkan hasil belajar peserta didik.

Berdasarkan kajian teoritis dan temuan-temuan penelitian diatas dapat dinyatakan bahwa model pembelajaran kooperatif tipe Think-Pair-Share dengan metode eksperimen dapat membantu peserta didik untuk mengembangkan pengetahuannya secara mendalam, karena peserta didik belajar dengan mengamati sendiri suatu proses melalui suatu percobaan, sehingga model pembelajaran kooperatif tipe Think-Pair-Share dengan metode eksperimen dapat meningkatkan hasil belajar fisika peserta didik.

\section{PENUTUP}

Berdasarkan hasil penelitian dan pembahasan yang telah dilaksanakan maka dapat ditarik kesimpulan bahwa model pembelajarankooperatif tipe Think-PairShare dengan metode eksperimen berpengaruh terhadap hasil belajar fisika peserta didik MAN Lombok Barat tahun pelajaran 2017/2018.

\section{REFERENSI}

Ampriyadi, I. 2014. Upaya Meningkatkan Hasil Belajar Siswa Melalui Model Pembelajaran Kooperatif Think Pair Share dalam Materi Tekanan Kelas VIII SMPN 1 Kalis. Jurnal Pendidikan Matematika dan IPA. 5(1): 46-53.

Azmi, M. K., Rahayu, S., dan Hikmawati. 2016. Pengaruh Model Problem Based Learning dengan Metode Eksperimen dan Diskusi Terhadap Hasil Belajar Fisika Ditinjau dari Sikap Ilmiah Siswa Kelas X MIPA SMAN 1 Mataram. Jurnal Pendidikan Fisika dan Teknologi. 2(2): 86-94.

Juraini., Taufik, M., dan Gunada, I. W. 2016. Pengaruh Model Pembelajaran Kooperatif Tipe STAD (Student Team Achievement Division) dengan Metode Eksperimen Terhadap Keterampilan Proses Sains dan Hasil Belajar Fisika pada Siswa SMA Negeri 1 Labuapi Tahun Pelajaran 2015/2016. Jurnal Pendidikan Fisika dan Teknologi. 2(2): 80-85.

Ni'mah, A., dan Dwijananti. P. 2014. Penerapan Model Pembelajaran Think Pair Share dengan Metode Eksperimen untuk Meningkatkan Hasil Belajar dan Aktivitas Belajar 
Siswa Kelas VIII MTs. Nahdlatul Muslimin Kudus. Jurnal Pendidikan Fisika. 3 (2): 18-25.

Nurilah, A. S., Sudarti., dan Nuriman. 2013. Pengaruh Model Kooperatif Tipe TPS dengan Metode Eksperimen disertai Teknik Concept Mapping Terhadap Sikap Ilmiah dan Hasil Belajar Fisika Siswa Kelas X di SMA Negeri 2 Tanggul. Jurnal Pendidikan Fisika. 2 (2): 184-189.

Nurqomariah, N., Gunawan., dan Sutrio. 2015. Pengaruh Model Problem Based Learning dengan Metode Eksperimen Terhadap Hasil Belajar IPA Fisika Siswa Kelas VII SMP Negeri 19 Mataram Tahun Pelajaran 2014/2015. Jurnal Pendidikan Fisika dan Teknologi. 1(3): 173179.

Setyosari, P. 2015. Metode Penelitian Pendidikan dan Pengembangan. Jakarta: Kencana.

Surayya, L., Subagia, I. W., dan Tika, I.N. (2014). Pengaruh model pembelajaran Think-Pair-Share terhadap hasil belajar IPA ditinjau dari keterampilan berpikir kritis siswa. Jurnal Pendidikan IPA Indonesia. 4(1): 85-92.

Trianto. 2014. Mendesain Model Pembelajaran Inovatif, Progresif, dan Kontekstual. Jakarta: Bumi Aksara.

Wahyuni, dan Hasanah. 2013. Pengaruh Penerapan Metode Eksperimen Dengan strategi Think- Pair-Share dalam Model Pembelajaran Diskusi Terhadap Hasil belajar Siswa Pada Materi Perpindahan Panas Di Kelas VII SMPNegeri 2 Buduran Sidoarjo. Jurnal Inovasi Pendidikan Fisika. 2(3):89-94.

Winayah, I. R., Sudarti, dan Nuriman. 2013. PenerapanModel Pembelajaran Kooperatif Tipe Think Pair Share dengan Metode Praktikum dalam Pembelajaran IPA Fisika Kelas VIII B SMPN 7Jember
Tahun Pelajaran 2012/2013. Jurnal Pembelajaran Fisika. 1(4): 102-108. 